\title{
Allocating the US Federal Budget to the States: the Impact of the President*
}

\author{
Valentino Larcinese ${ }^{1}$ \\ Department of Government and STICERD \\ London School of Economics and Political Science \\ Leonzio Rizzo \\ Department of Economics \\ University of Ferrara \\ Cecilia Testa \\ Department of Economics \\ Royal Holloway College
}

$\mathrm{PEPP} / 3$

June 2005

Political Economy and Public Policy Series The Suntory Centre

Suntory and Toyota International Centres for Economics and Related Disciplines

London School of Economics and Political Science

Houghton Street

London WC2A 2AE

2005

Tel: (020) 79556674

\footnotetext{
* Acknowledgements: We wish to thank Tim Besley, Robert Franzese, Jim Snyder and Cristiana Vitale for helpful discussions and suggestions and the participants to seminars at STICERD, Royal Holloway College, Ente Einaudi, LSE, Bocconi University, FGV, USP, LAMES 2004 Santiago, PET04 Beijing, the Public Economics week end at the University of Essex and the 2005 meeting of the Midwest Political Science Association for their useful comments. Remaining errors are only ours.

1 Address for correspondence: London School of Economics, Department of Government, Houghton Street, London, WC2A 2AE, United Kingdom, Tel. +44 (0) 207955 6692. Fax: +44 (0) 207955 6352. E-mail: V.Larcinese@1se.ac.uk.
} 


\begin{abstract}
This paper provides new evidence on the determinants of the US federal budget allocation to the states. Departing from the existing literature that gives prominence to Congress, we carry on an empirical investigation on the impact of Presidents during the period 1982-2000. Our findings suggest that the distribution of federal outlays to the States is affected by presidential politics. First, presidential elections matter. States that heavily supported the incumbent President in past presidential elections tend to receive more funds, while marginal and swing states are not rewarded. Second, party affiliation also plays an important role since states whose governor has the same political affiliation of the President receive more federal funds, while states opposing the president's party in Congressional elections are penalized. These results show that presidents are engaged in tactical distribution of federal funds and also provide good evidence in support of partisan theories of budget allocation.
\end{abstract}

Keywords: Federal Budget, Pork-Barrell, President, Congress, Political Parties, Committees, American Elections.

JEL: D72, H61, H70

(C) The authors. All rights reserved. Short sections of text, not to exceed two paragraphs, may be quoted without explicit permission provided that full credit, including $\odot$ notice, is given to the source 
"For republican governors, it means we have an ear in the White House, we have a number we can call, we have access that we wouldn't have otherwise had, and that's of course helpful" ( Gov. Mitt Romney, Washington Post, Monday, November 22, 2004)1

\section{Introduction}

The allocation of the federal budget in the United States is the outcome of a complex process involving numerous institutional players. A vast theoretical and empirical literature has devoted a formidable effort to the study of this process. The existing empirical contributions primarily focus on congressional influence via powerful individual representatives, such as for example committee members, or via political parties. The executive, however, also plays an important role in the budget formation: the president initiates the process by sending a proposal to the Congress and, once the budget has been approved, retains a veto power that can be overridden only by a qualified majority equal to $2 / 3$ of Congress.

Historically, the balance of power between president and Congress over the budget has been subject to important changes. The authority of the executive over initiation of the budget was first established by the Budget and Accounting act of 1921 that began a long lasting period of domination of presidency over Congress. Following the escalating conflict with the Nixon administration, the Congress tried then to regain control over the budget through the Budget Impoundment and Control act of 1974. According to Schick (1979), the 1974 reform "has the potential of altering presidential-Congress relationship contributing to a resurgence of Congress". A number of scholars, however, argue that the president is still an influential player (Kiewiet and Krehbiel, 2000; Edwards, 1980 ) mainly because of his veto power (Copeland, 1983; Rhode and Simon, 1985; Kiewiet and McCubbins, 1988; McCarty, 2000), since "merely the threat of a veto is often enough to force Congress to tailor a bill conform to administration wishes"(Cumming and Wise,1981).

\footnotetext{
${ }^{1}$ Interview with Republican governor Mitt Romney, following the re-election of $G . W$. Bush in November 2004.
} 
In this paper we ask whether the president has a systematic impact on the allocation of the federal budget to the states. Evidence of presidential influence on the territorial distribution of federal funds has been provided by several studies on the New Deal program. In particular, Wright (1974) and Wallis (1987), have found that states with high volatility of presidential vote received more federal support, which is consistent with the idea that the president might try to target swing voters ${ }^{2}$. On the other hand, Anderson and Tollison (1991) and Couch and Shughart (1998) find a positive correlation between Roosvelt share of votes in 1932 and spending at state level ${ }^{3}$ that is compatible with the hypothesis of rewarding loyal rather than swing voters. Finally, Fishback et al.. (2003) and Fleck (2001) find evidence in support of both hypotheses ${ }^{4}$.

While the New Deal has received great attention, there is a lack of empirical studies on presidential influence after the 1974 reform. Is the presidential impact still relevant or does Congress now dominate federal budget allocation? In this paper we attempt to answer this question by providing new empirical evidence on contemporary federal budget allocation to the states.

From a theoretical point of view, the executive may have several reasons to sway the federal budget allocation away from a purely social welfare maximizing objective (McCarty, 2000). Namely, the president may use budget allocation to enhance his reelection chances either by targeting swing states or by rewarding his supporters. Lindbeck and Weibull (1987 and 1993) provide theoretical models explaining why political actors should redistribute funds to marginal and swing states in order to maximize their chances of winning elections. Cox and McCubbins (1986) argue instead that, because of the ideological relationship between voters and candidates, more funds should be allocated where policy-makers have larger support. In particular, the targeting of loyal voters can be seen as a safer investment as compared to aiming for swing voters. Hence, risk adverse political actors that want to maximize the chances of winning elections, should allocate

\footnotetext{
${ }^{2}$ Stromberg (2004) shows, however, that these findings are not robust to the inclusion of state fixed effects.

${ }^{3}$ Anderson and Tollison (1991) also find evidence of committee influence on New Deal Spending.

${ }^{4}$ For an overview of the literature on New Deal spending see Couch and Shughart (1998) and Fishback et al. (2003).
} 
more funds to loyal states. Dixit and Londregan (1996) provide an alternative model where politician face incentives to target both swing and loyal voters. On the one hand, moderate voters, who are indifferent between two parties, can more easily be bought; on the other, core supporters can be targeted in a more efficient way because parties know their preferences better.

Besides targeting specific groups of voters, the president could also try to further his legislative agenda by directing spending to specific legislators. Moreover, "as a leader of his party, he may feel the pressure to favor legislative districts controlled by members of his party" (McCarty, 2000). Assuming that party reputation is a public good for individual party members, Cox and McCubbins (1993) provide a theoretical explanation for cooperation among representatives belonging to the same party ${ }^{5}$. Along the same line, Dasgupta et al. (2004), argue that when the electoral returns from spending are shared between state and central government, then transferring funds to a governor of the opponent party generates a "leakage" effect whereby the central government looses part of the electoral benefit from spending. Finally, if state governments have some discretion in the way funds are spent, then the federal administration could prefer to allocate more funds to governors with the same policy preferences. All this seems to suggest that the president has incentives to sway the allocation of federal funds in the direction of "friendly" administrators.

This study will test these alternative theories of presidential influence. In particular, we will first estimate the effect of the presidential electoral race on the budget allocation to find out whether the president rewards his supporters or whether he targets states that are marginal or swing in presidential elections. Second, to uncover whether the president diverts federal funds toward states controlled by members of his party, we will estimate the effect of partisan alignment between the president and the state governors and/or state representatives.

The impact of the president as a party leader and, more generally, the distributive

\footnotetext{
${ }^{5}$ The evidence reported by the media on cooperation between party members is abundant. During presidential campaigns a huge emphasis is placed, for example, on the ability of governors to deliver the votes of their state.
} 
effects of cooperation between representatives belonging to the same party, are important theoretical questions that have not been explored yet by the empirical literature on partizan budgeting, that tends instead to focus on the role of parties inside Congress. Among the contributions on congressional partizan budgeting, Levitt and Snyder (1995) find that, when Congress was dominated by democratic majorities, outlays at the district level were positively correlated with the district share of democratic votes ${ }^{6}$. Similarly, Carsey and Rundquist (1999) find that states represented by Democrats on a defense committee receive more military procurement awards. Bickers and Stein (2000) find that the Republican control of the 104th Congress altered the composition of federal outlays in favor of programs that are more compatible with the interests of Republican representatives $^{7}$.

One important advantage of our empirical analysis is that it relies on panel data on federal outlays over a relatively long time span. The panel structure allows us to use state fixed effects to account for state-level unobserved heterogeneity and identify the effect of the relevant political and economic variables ${ }^{8}$. Since the president, unlike most other individual players, can exercise his influence on any budgetary aggregate, we decided to focus our attention on total federal outlays. This approach has its own drawbacks but, for our purposes, also provides substantial advantages. Focussing on very specific aggregates, as most literature does, makes it possible to shed light on specific forms of influence and to be very precise on them. This is particularly true for studies on committees, where distortions are more often found on specific spending programs. It is, however, quite possible that the distortions introduced by different actors with limited influence may offset each other leaving a state without a real advantage in the overall allocation of federal funds. Since the presidential influence is not limited to particular aggregates,

\footnotetext{
${ }^{6}$ Evidence of a bias in favour of democratic districts is also reported by Owens and Wade (1984), Alvarez and Saving (1997) and Kiewiet and McCubbins (1985). Some recent literature has investigated the role of parties on budget allocation also in other countries. Dasgupta et al. (2001) find that Indian states ruled by the same party that controls the central goverment receive more grants, while Dahlberg and Johansson (2000) find that the Swedish regions that are "swing" in the national elections receive a higher share of a specific transfer program.

${ }^{7}$ They find, for example, a remarkable increase in the pro-business contingent liabilities.

${ }^{8}$ When data on specific years are used instead, it is hard to say if the results obtained are merely due to particular features of the data considered or to proper and long lasting political influence.
} 
then it is more likely that a state can be favoured in the overall budget allocation for reasons related to presidential politics. Therefore, total federal spending is the place where the presidential influence is more likely to be detected. Focussing on whether a state receives, on aggregate, more federal funds we are of course capturing only a particular channel through which political actors may divert funds toward their constituencies. The composition of the budget is another instrument that can be used to favour interests located in a given constituency, as it is shown by Bickers and Stein (2000).

While we are primarily interested in the role of the president, we also incorporate into the analysis the other relevant institutional players (Congress and committees) because excluding some explanatory variables in the regressions may lead to the well known problem of omitted variable bias ${ }^{9}$. Therefore, we check the robustness of our results by simultaneously estimating in the same regressions the impact of several channels of political influence that, according to previous studies, may crucially affect federal budget allocation. Following Atlas et al. (1995) and Lee (1998), we control for overrepresentation of small states in Congress. Furthermore, individual representatives occupying key positions in the budget process can convey disproportionate amount of money to their districts (Fenno 1973, Kiewiet and McCubbins, 1988) and according to several scholars, committees are very influential in determining the budget allocation (Shepsle and Weingast 1987) since they have an advantage both in terms of their agenda setting power (McKelvey and Ordeshook, 1980) and in terms of information and competence ${ }^{10}$ (Krehbiel, 1991). Hence, we follow the empirical literature on committee influence ${ }^{11}$ and introduce committee membership in our analysis.

To briefly summarize our main results, we find that the president has an important

\footnotetext{
${ }^{9}$ When different explanatory variables are correlated, as it seems reasonable to expect in most cases, omitting relevant players could deliver biased estimates of the impact of those considered.

${ }^{10}$ Weingast and Marshall (1988) argue that committees are the devices that make logrolling work, by facilitating the trade of influence in the absence of a spot market for the exchanging of support.

${ }^{11}$ The empirical literature on committee influence is vast and, although the results are sometimes mixed, committee influence is usually found on specific spending categories rather than large spending aggregates. Among the numerous studies on committees see Plott (1968), Goss (1972), Ferejohn (1974), Ritt (1976), Strom (1975), Rundquist and Griffit (1976), Ray (1981), Kiel and McKinzie (1983), Rich (1989), Anderson and Tollison (1991), Owens and Wade (1984), Alvarez and Saving (1997), Carsey and Rundquist (1999), Levitt and Poterba (1999), Aldrich and Rhode (2000) Bond et al. (2004), Knight (2004). For an overview on the Committee influence literature see Bond et $A l$ (2004).
} 
impact on the allocation of the budget to the states. In particular, states that ideologically lean towards the president, i.e. states with a high share of presidential votes or with a governor belonging to the party of the president, tend to be rewarded with more funds. On the other hand, states with a close presidential electoral race and states that either changed political affiliation in the most recent election or that are historically volatile do not receive more money. Hence, overall our analysis suggests that the president is a relevant player as he can direct more funding toward those states that are run by "friendly" governors and that have large groups of "core supporters". Finally, our analysis indicates that partisanship plays an important role since governors politically aligned with the president receive more resources and Congress members opposing the president bring less funds to their states.

The remainder of the paper is organized as follows. The next section describes our dataset and lays out our empirical approach. Section 2 presents our main results. In section 3 we provide our conclusions.

\section{Data and methodology}

Following the theoretical literature on partizan budgeting (Lindbeck and Weibull,1987 and 1993; Dixit and Londregan,1996; Cox and McCubbins, 1986) and presidential influence (McCarty, 2000; Kiewiet and Krehbiel, 2000) the hypotheses we want to test may be summarized as follows:

H1: federal funds are disproportionately targeted to states that are marginal and swing in presidential elections (swing bias);

H2: federal funds are disproportionately targeted to states where the president is supported by a large share of the electorate (ideological bias);

H3: party alignment of state governors and/or Congress representatives with the executive increases the receipt of federal funds (party alignment). For completeness, we also check what is the impact of the alignment of governors and state representatives with Congress majorities. 
We use data on federal outlays for the 48 US continental states from 1982 to $2000^{12}$. In Table 1 we report average per capita federal outlays during the period 1982-2000 (expressed in real $\$$ for the year 2000). It is immediately clear that the differences in spending can be substantial. An average resident of Virginia, for example, has received every year almost $\$ 2,700$ more than an average resident of Wisconsin. While this gap can be entirely due to the needs and characteristics of the respective populations, it is legitimate to ask how much of this difference can be due to purely political factors. For this purpose we estimate the following equation:

$$
\begin{aligned}
F E D E X P_{s t} & =\alpha_{s}+\beta_{t}+\boldsymbol{\theta}_{1} \mathbf{P}_{s w}^{i}+\boldsymbol{\theta} \mathbf{Z}_{s t}+\epsilon_{s t} \\
s & =1, \ldots 48 ; \quad t=1982, \ldots 2000
\end{aligned}
$$

where $F E D E X P_{s t}$ is the real per-capita federal expenditure (outlays) in state $s$ at time $t$. As in all the subsequent regressions, we include state fixed effects and year dummies. $\mathbf{Z}_{s t}$ is a vector that includes real income per capita, state population, unemployment rate, percentage of citizens aged 65 or above and percentage of citizens between 5 and 17 years old. We keep these explanatory variables in all the regressions as standard economic and demographic controls. Finally, $\mathbf{P}_{s w}^{i}$ represents the set of institutional and political variables under consideration ${ }^{13}$.

It is important to point out that in the US budget process there is a lag between the appropriation of federal funds and the moment when these are actually spent. This is relevant when estimating the effect of particular institutional and political variables, since current federal outlays have normally been appropriated in previous budgetary years. Delays should therefore be taken into account. Hence, we introduce lagged values for $\mathbf{P}_{s t}^{i}$, since past policy makers are responsible for current outlays. To give the right weight to lagged independent variables explaining current outlays, we use weighted averages of

\footnotetext{
${ }^{12}$ As customary, Alaska, District of Columbia and Hawaii have been excluded. Usually those states tend to be excluded to facilitate comparison with previous research. Another reason, and probably a better one, however, is that they attract a disproportionate amount of federal spending for either aministrative reasons (DC) or strategic reasons (Alaska and Hawaii receive a substantial share of defense spending). This could render the political motivations behind an observed distribution less recognizable.

${ }^{13}$ Summary statistics are reported in the Statistical Appendix.
} 
lagged $\mathbf{P}_{s}^{i}$, where the weights are determined by the spend-out rates utilized in official forecasts. Hence, since we know that approximately $60 \%$ of aggregate federal expenditure is spent within one year, and assuming that the rest is spent two years later, we regress outlays at time $t$ on the weighted average of two lagged variables, i.e. $\mathbf{P}_{s w}^{i}=0.6 * \mathbf{P}_{s t-1}^{i}+$ $0.4 * \mathbf{P}_{s t-2}^{i}$.

Hypotheses 1 and 2. We begin our analysis by considering the role of electoral competition in the presidential electoral race. Hence, we compare the relative impact of the closeness of the presidential elections in each state with that of the share of votes obtained by the president in the last election ${ }^{14}$. A negative sign of the closeness variable should be regarded as support for the idea that the president tends to direct resources to marginal states in order to increase his chances of re-election. A positive sign of the share of presidential votes should instead be seen as evidence that incumbents tend to reward states that show their support in elections. We also take into account the fact that not all states have the same weight in presidential elections by including the number of electoral votes per capita by state.

The closeness of the past election is, however, not necessarily the best measure to identify swing states. We, therefore, generate an indicator of long term swing which is based on the number of times a state swung its support from a party to another in last four presidential elections ${ }^{15}$.

Hypothesis 3. As previously discussed, the partisanship of different representatives can have an important effect on budget allocation since cooperation between different political actors belonging to the same party is likely to occur. In particular, the president acting as a party leader may divert funds toward state governors and state representatives

\footnotetext{
${ }^{14}$ Hypothesis 1 and 2 are different because, although correlated, the closeness and the presidential share of votes measure two separate electoral phenomena. First, they can be different when there are more than two candidates. More importantly, however, they are different because while an electoral race can be equally "close" in states where the president has won or lost to the opponent, the share of presidential votes will necessarily be different when the president wins.

${ }^{15}$ We have also used two other measures of electoral volatility. One is a moving average of the frequency of swings from one party to the other that starts from the 1964 election. The other is an indicator of short term volatility represented by a dummy equal to one for the states that switched their support in the last election. Our results do not change when we use such alternative measures. Further details can be found in the online statistical appendix.
} 
belonging to his own party. Hence, we consider a series of dummy variables to capture various levels of partizan alignment between central powers and state governments. We first create three dummy variables to reflect the political alignment of state governors with, respectively, the president and the majorities in the House and in the Senate. In a further specification we also consider the possibility that funds allocation to a given state is facilitated by party alignment between the governor and the majority of state delegates to the House or the governor and both senators. We then consider the potential effect of having the president and a majority of state delegates in the House, or the president and both senators from a given state, belonging to the same party. Finally, we consider the potential advantage of having a majority of state delegates to the House belonging to the House majority party or having both senators belonging to the Senate majority.

We are aware that testing our hypotheses separately has a major limitation because, by considering one element at time, we can miss relevant correlations and incorrectly estimate some effects. For this reason we run a regression including all the $\mathbf{P}_{s w}^{i}$ vectors in one equation of the form:

$$
F E D E X P_{s t}=\alpha_{s}+\beta_{t}+\sum_{i} \boldsymbol{\theta}_{1}^{i} \mathbf{P}_{s t}^{i}+\boldsymbol{\theta}_{2} \mathbf{Z}_{s t}+\epsilon_{s t}
$$

The results we get from equation (3) provide the big picture that is missed when focussing on specific channels of influence and provide an important robustness check.

\section{Results}

\subsection{Swing and Ideological Bias}

In Table 2 we focus on presidential elections to test the swing voter hypothesis and contrast it with the potential presence of ideological bias. Column 1 shows that, while the share of presidential votes in the past election displays a positive and significant coefficient, the closeness of the same election has no significant effect ${ }^{16}$. In column 2 we consider the swing

\footnotetext{
${ }^{16}$ Concerning the economic variables, states with higher income per-capita receive significantly less, as do states with larger population. The percentage of aged population also has a positive and significant
} 
variable and we find again no evidence in support of the swing voter hypothesis, while the share of presidential vote has always a positive and significant effect ${ }^{17}$. Depending on the specification considered, the difference in spending between a state with maximum share of presidential vote and a state with the minimum of such share goes from $\$ 536$ (column 1) to $\$ 908$ (column 2) per capita per year, which implies that one standard deviation in the share of presidential vote is worth $97-164 \$$. These findings are in line with some of the existing literature. For example, Anderson and Tollison (1991) and Couch and Shughart (1998) find a positive correlation between spending at the state level and Roosvelt share of votes in 1932, and Wright (1974) finds no effect of the closeness of the presidential race $^{18}$.

To summarize, we find that the ideological bias toward safe states is substantial in terms of both magnitude and statistical significance. We do not find instead any evidence of the refined targeting of swing and marginal states that some formal models seem to suggest. Assuming that electors cast their vote depending on the amount of spending they receive and also on their ideological affinity to a party, the swing voter bias should come from the fact that moderate voters (who are indifferent between two parties) can be more easily convinced to switch their vote in favor of the party that has rewarded them with spending. However, as Dixit and Londregan (1996) point out, the electoral return from a dollar of spending is higher when targeted to an electorate whose preferences the politician understands well. Hence, although the vote of the moderate electors may be "cheaper" to buy, the informational advantage and ability of parties to target funds more efficiently to their supporters can explain why allocating more spending to states with

effect. The percentage of children in schooling age has instead a negative and significant effect, while the unemployment rate is completely uncorrelated with aggregate spending per capita. The signs and significance of those coefficients remain substantially the same in all the subsequent specifications.

${ }^{17}$ One obvious concern is that the significance of our estimates could be heavily conditioned by multicollinearity among the independent variables. To verify that the correlations of our predictors do not significantly inflate the estimation of their standard errors, we calculate the Variance Inflation Factor for all the regressions we present in this work. Here, as well as all the subsequent regressions, we find that that multicollinearity has a very limited impact on the results of all the regressions. A description of the methodology and detailed results are reported in the statistical appendix.

${ }^{18}$ Our results are also consistent with the findings of Stromberg (2004), who shows how, when state fixed effects are included in the regressions, evidence that swing states received more federal support under the New Deal vanishes. 
many loyal voters can deliver a better electoral return than targeting areas with many swing voters.

\subsection{Party Alignment}

In this section we explore the effect of partizan alignment between central and state government. Our analysis provides support for the idea that partisanship matters and that political actors exchange favors and policies within the party boundaries. Column 1 of Table 3 shows that the coefficient of the alignment between the president and the governor in a given state has a positive and statistically significant impact. The size of the coefficient is also relevant, implying a transfer of approximately $135-138 \$$ per capita per year. On the other hand, we find that the effect of alignment of governors with the majority in either chamber of Congress is not significant. This is especially important because it shows both the relevance of party affiliation at different levels of governance and the prominent role of the president in the budget process as a party leader.

In column 2, we include other alignment variables. The significance and magnitude of the alignment between governors and the president appears unaffected by the introduction of new variables. Other alignment variables appear to have no statistically significant impact. The only exception is represented by having a majority of state delegates to the House belonging to the same party of the president. This again suggests that the widespread emphasis on the role of the House in the allocation of the federal budget can obscure the important role played by both the president and the party affiliation ${ }^{19}$.

The role of parties in American politics has been reconsidered in recent research and new evidence about party cohesion casts some doubts on the common view that American parties are weak organizations, with limited ideological divide (Rohde, 1991). If parties are influential, then the president, as a party leader, may favor legislative districts controlled

\footnotetext{
${ }^{19}$ To take into account possible multicollinearity we also run separate regressions for different forms of alignment. The results (available in the online statistical appendix) remain unchanged, with the exception of the alignment between the majority of state delegates and the House Majority, which has now a negative impact. This is not surprising if we consider that the House has been mostly opposed to the president in the period we consider (with the exception of the period 1993-94). To confirm this, when we directly include alignments with the President (column 2 of Table 3), this result vanishes.
} 
by members of his party. By showing that the president is able to target more funds toward states that are controlled by state governors belonging to his party, we find good evidence in support of the theoretical literature that gives prominence to political parties and party leaders in shaping public policies. Consistently with Levitt and Snyder (1995), who find that democratic districts received more federal spending under the Carter administration than under the Reagan administration, we also find that state representatives opposing the president bring less funds to their states as compared to representatives aligned with the president.

For what concerns the relationship between the president and the state governors, Carsey and Wright (1998) find that votes in gubernatorial elections crucially depend on presidential approval rate. On the other hand, governors can play an important role in presidential elections as suggested by the attention the media devote to the ability of state governors to "deliver" the vote of their state. The casual evidence on the privileged partizan link between president and governors is abundant ${ }^{20}$. The endorsement of governors also plays a fundamental role in the selection of presidential candidates during primaries ${ }^{21}$ and the governors associations underline their important role in shaping federal policies ${ }^{22}$. Uncovering that the partisanship of state governors and president is an important determinant of the distribution of federal funds to the states, our study provides evidence of an effective link between governors and the president through political parties.

\subsection{Robustness}

We now check if our results are robust to a different specification, in which various effects are considered at the same time. In Table 4 we test simultaneously the different, though

\footnotetext{
${ }^{20}$ In a recent interview, following the recent US presidential election of 2004, Mitt Romney, Governor of Massachussets declared that "for republican governors, it means we have an ear in the White House, we have a number we can call, we have access that we wouldn't have otherwise had, and that's of course helpful" (Gov. , Washington Post, Monday, November 22, 2004)

${ }^{21}$ The Republican Governors' Association reports that "Presidential candidates hailing from out of state can trade on a governor's name cachet and fund-raising network, while governors can gain a powerful ally in the Oval Office if their horse wins the race" (Larry Sabato on interview the by Kenneth P. Vogel,Wednesday June 18, 2003, The News Tribune).

${ }^{22}$ Both the Republican and Democratic Governors' Associations explicitely state on their website their intent to influence federal policies.
} 
not necessarily conflicting, hypotheses.

From columns 1 it is clear that all the results previously obtained on individual variables (or group of variables) are substantially confirmed by this check. In particular, the share of votes for the president and the party alignment between the president and the governors have a positive impact and are statistically significant at the $5 \%$ level. The alignment of the president with the majority of state delegates in the House is positive and significant at $10 \%$ level. As discussed in the previous section, many reasons can induce a president to support friendly governors. To shed further light on this relationship, in column 2 we introduce a dummy equal to 1 if the state has a gubernatorial election in a given year and we also interact this dummy with the governor-president alignment variable. If the president supports the re-election prospects of friendly governors then the interaction term should be positive. This turns out to be the case: while the size and significance of all other variables are only marginally affected, presidents appear to support friendly governors particularly in their re-election years. This corroborates our findings about both the presidential pork-barrel and the privileged relationship with governors from the same party.

In column 3 we add a number of further controls that previous studies have identified as determinants of the federal budget allocation. We consider the role of committee membership, focussing on the most influential committees in the budget process. We use as explanatory variables the number of members by state in the Appropriation, Budget, Ways and Means, and Rules committees of the House. We also include the electoral turnout in presidential elections and a dummy variable for having a democratic president. To take into account overrepresentation we follow Atlas et al. (1995) and introduce the number of senators per capita. We find that having a democratic president substantially increases overall spending (more than $1000 \$$ yearly per capita). Overrepresentation is positive and significant ${ }^{23}$. We do not find any evidence that turnout has any impact on the allocation process. Finally we find that having members in the Ways and Means committee has a positive effect (around $76 \$$ per capita per member). This confirms the

\footnotetext{
${ }^{23}$ One standard deviation in the number of Senators per capita is worth around 1,200 $\$$ in per capita spending. This is consistent with the finding of Atlas et al. (1995).
} 
results that Alvarez and Saving (1997) obtain in their cross-section study. On the other hand, we do not find evidence that other prestige committees distort federal funds ${ }^{24}$. Concerning our main variables of interest, we find that the gain from electing a majority of delegates in the House who are on the president's side is almost $100 \$$ per capita. Again, we find that the party alignment between the president and the governor, as well as the share of presidential votes in the last election, positively affect federal expenditure. The magnitude of the governor-president alignment variable is virtually insensitive to the change in specification and, also in this case, we find that substantially more funds are received by friendly governors during their re-election year.

To sum up this section, our results are quite robust to changes in the specification adopted and to joint consideration of various theories. We find that economic and demographic characteristics are very important explanatory variables of the allocation of the budget to the states, but are not sufficient to explain the disparities in the amounts received. Some states receive disproportionate amounts of money for reasons essentially linked to politics and to the budget allocation process. In particular, we find that the president turns out to have an important role. We also provide support for partisan theories, since there is evidence that the president rewards his "core voters" and members (governors and representatives) of his own party.

\section{Conclusions}

A common view about the US federal budget is that the president influences the big macroeconomic aggregates while individual congressmen bargain over the territorial distribution of funds in order to bring resources to their constituents. This study shows that presidents are also engaged in tactical distribution of federal funds to the states. This conclusion is supported by a number of findings concerning the relation of federal spending with both the results of presidential elections and the party affiliation of the president. States that display large support for the presidential party tend to be rewarded. States

\footnotetext{
${ }^{24}$ These findings seem consistent with the existing literature, which tend to show that the effect of committees can usually be found on very specific spending programs rather than on large aggregates.
} 
where the governor belongs to the same party of the president receive more founds, while states that have a delegation in the House which is predominantly opposed to the president tend to be penalized. These results also seem to show that parties are important players and that the president tend to act as a party leader.

Congressional pork-barrel is often viewed as a common and almost inevitable consequence of representative democracy where elected representatives use federal funds in order to buy political support. However, presidents themselves, as elected representatives of broader constituencies, are not immune from the same problem. Starting from the '80, all presidencies have put forward proposals for the introduction of presidential line item veto ${ }^{25}$ and expanded impoundment control aiming at increasing the power of the president to control unnecessary congressional pork-barrel spending. These proposals have raised the suspicion of a possible change in the balance of power between executive and Congress mainly because the impoundment power, before the 1974 budget act, has been extensively used by the presidency to override congressional budget priorities. However, whether this shift in power might be desirable or not depends, among other factors, on whether the executive could be a more effective body in controlling pork-barrel spending. Our study casts some doubts on the disciplining role of the executive and suggests that the arguments for increasing the power of the president on budgetary matters should be taken with due caution.

Our findings also shed light on alternative theories of electoral competition. We find that states with large share of presidential supporters get more funds, but we do not find that more federal monies are allocated to marginal or swing states. This evidence, while corroborating the hypothesis of ideological bias formalized by existing theoretical models, also suggests that further theoretical research on the ongoing link between parties and "core supporters" would be very important to better understand distributive politics. If one investigates the reasons behind voters' loyalty, then it is hard to justify why loyal

\footnotetext{
${ }^{25}$ The line item veto was introduced in 1997 under the Clinton administration, but was declared unconstitutional only one year later. Recently, in a news conference on November 2004 president G.W. Bush has re-iterated the administration wish for the re-introduction of the line-item veto. For an overview on the proposals of line item veto see Fisher (2004).
} 
voters should support political actors that systematically allocate funds to the advantage of swing voters. Hence, in a context of repeated interactions between the electorate and the politicians, loyalty in itself can be sustained only if political actors build a reputation of rewarding their supporters. The need for such a long term perspective provides a further rationale for the importance of parties in the process of allocating federal resources.

Further empirical research is certainly necessary to gain more insights on presidential pork barrel. In particular, an analysis of disaggregated spending categories could be useful in order to find out if there are budget aggregates which are more prone to presidential manipulation and whether different spending categories are used to achieve different goals ${ }^{26}$. Nevertheless, by using panel data on a relatively long time span and by testing various theories on the same dataset, we reached new and robust findings. These results help in evaluating the validity of current theories and, importantly, call for new theoretical developments in order to understand the long term reputation game between voters and political actors.

\footnotetext{
${ }^{26}$ Since cooperation between members belonging to the same party can also be due to policy motivation, it could happen that, when state governments have more discretion on how to spend certain funds, the bias toward friendly governors might be bigger. An investigation along those lines goes beyond the scope of this paper, but this is an interesting empirical question that we leave for further research.
} 


\section{References}

[1] Alvarez, Michael R. and Jason L. Saving. 1997. Congressional committees and the political economy of federal outlays, Public Choice 92: 55-73.

[2] Anderson, Gary. M. and Robert D. Tollison.1991. Congressional Influence and Patterns of New Deal Spending, Journal of Law and Economics 34: 161-75.

[3] Atlas, Cary M., Thomas W. Gilligan, Robert J. Hendershott and Mark A. Zupan. 1995. Slicing the Federal Government Net Spending Pie: who wins, who loses, and why, American Economic Review 85: 624-629.

[4] Bickers Kenneth N. and Robert M. Stein. 2000. The Congressional Pork in a Republican Era, Journal of Politics 62: 1070-1086.

[5] Bond, James .R., Emily M. Bonneau, and Jon B.Cottril. 2004. The House Public Works Committee and the Distribution of Pork-Barrel Projects. Chicago: APSA meeting Proceedings.

[6] Carsey Thomas M., and Gavin Wright. 1998. State and National Factors in Gubernatorial and senatorial Elections, American Journal of Political Science 42:994-1002.

[7] Carsey Thomas M. , and Barry Runquist. 1999. Party and Committees in Distributive Politics: Evidence from Defence Spending, Journal of Politics 61:1156-1169.

[8] Copeland, Gary W. 1983. When Congress and president Collide: why presidents veto legislation, Journal of Politics 45:696-710.

[9] Couch, Jim F. and William F. Shugart II .1998. The Political Economy of New Deal Spending, Cheltenham, UK: Edward Elgar.

[10] Cox, Gary W. and Matthew D. McCubbins. 1986. Electoral Politics as a Redistributive Game, Journal of Politics, 48: 370-389.

[11] Cox, Gary W. and Matthew D. McCubbins. 1993. Legislative Leviathan: Party government in the House, Berkeley: University of California Press. 
[12] Dasgupta, Sugato, Amrita Dhillon and Bhaskar Dutta. 2004. Electoral Goals and Centre-State Transfers: A theoretical Model and Empirical Evidence from India. Unpublished Manuscript.

[13] Dixit, Avinash and John Londregan. 1995. Redistributive Politics and Economic Efficiency, American Political Science Review 89: 856-66.

[14] Dixit, Avinash and John Londregan. 1996. The Determinant of Success of Special Interests in Redistributive Politics, The Journal of Politics 58:1132-1155..

[15] Dahlberg, Matz and Eva Johannsson. 2002. On the Vote-Purchasing Behavior of Incumbent Governments, American Political Science Review 96: 27-40.

[16] Edwards, George C. III.1980. presidential Influence in Congress, San Francisco: W. H. Freeman.

[17] Fenno, Richard F. 1966. The Power of the Purse, Boston: Little Brown.

[18] Fenno, Richard. F.1973, Congressmen in Committees, Boston: Little Brown.

[19] Ferejohn, John A. 1974. Pork Barrel Politics, Stanford: Stanford University Press.

[20] Fishback, Price V., Shawn Kantor, and John J. Wallis. 2003. Can the New Deal three-R's be Rehabilitated? A county-by-county, program-by-program analysis, Explorations in Economic History 40: 278-307.

[21] Fisher, Louis. 2004. A presidential Item Veto, CRS Report for Congress.

[22] Fleck, Robert K. 2001a. Inter-party Competition, Intra-party Competition and Distributive Politics: a model and test using New Deal data, Public Choice 108: 77-100.

[23] Goss, Carol F. 1972. Military Committee Membership and Defense-Related Benefits in the House of Representatives, The Western Political Quarterly 25: 215-33.

[24] Kiewiet, D. Roderick, and Matthew D. McCubbins.1985. Congressional Appropriations and the Electoral Connection, Journal of Politics 47: 59-82. 
[25] Kiewiet, D. Roderick, and Matthew D. McCubbins. 1988. presidential Influence on Congressional Appropriation Decisions, American Journal of Political Science 32:713-736.

[26] Kiewiet, D. Roderick, and Keith Krehbiel. 2002. Heres the president, Wheres the Party? U.S. Appropriations on Discretionary Domestic Spending, 1950-1999, Leviathan 30: 115-37.

[27] Krehbiel D. Roderick,.1991. Information and Legislative Organization, University of Michigan Press.

[28] Krehbiel, D. Roderick, Kenneth A. Shepsle, and Barry R. Weingast. 1987. Why Are Congressional Committee Powerful, American Political Science Review 81: 929-945.

[29] Levitt, D. Steven, and James J. Snyder. 1995. Political Parties and the Distribution of Federal Outlays", American Journal of Political Science 39: 958-980.

[30] Lindbeck, Assar S. N. and Jörgen W. Weibull. 1987, Balanced-budget redistribution as the outcome of political competition, Public Choice 52: 273-297

[31] Lindbeck, Assar S. N. and Jörgen W. Weibull.1993. A Model of Political Equilibrium in a Representative Democracy, Journal of Public Economics 51: 195-209.

[32] McCarty,Nolan M. presidential Pork: Executive Veto Power and Distributive Politics, The American Political Science Review, 94: 117-129.

[33] McKelvey, Richard. D., and Peter C. Ordeshook. 1980. Vote Trading: An Experimental Study, Public Choice 35: 151-84.

[34] Owens, John R. and Larry L. Wade. 1984. Federal Spending in Congressional Districts, The Western Political Quarterly 37:404-23.

[35] Plott, Charles. 1968. Some Organizational Influences in Urban Renewal Decisions, American Economic Review 58:306-311. 
[36] Ray, Bruce A. 1981. Military Committee Membership in the House of Representative and the Distribution of Federal Outlays, Western Political Quarterly, 34: 222-34.

[37] Rich, Michael J. 1989. Distributive Politics and the Allocation of Federal Grants, The American Political Science Review 83:193-213.

[38] Ritt, Leornard G. 1976. Committee Position, Seniority and the Distribution of Government Expenditures, Public Policy 24:469-97.

[39] Rodhe, David. 1991. Party and Leaders in the Postreform House, Chicago: University of Chicago Press.

[40] Rodhe, David and Dennis M. Simon. 1985. presidential Veto and Congressional Response: A Study of Institutional Conflict, American Journal of Political Science 29:397-427.

[41] Rundquist, Barry S. and David E. Griffith. 1976. An Interrupted Time-Series Test of the Distributive Theory of Military Policy-Making, The Western Political Quarterly, 29: $620-626$.

[42] Schick, Allan.1979. Whose Budget?, The Presidency and the Congress: A Shifting Balance of Power? edited by W. S. Livingston, L. C. Dodd and R. L., Lyndon B. Johnson School of Public Affairs : Lyndon Baines Johnson Library.

[43] Shepsle, Kenneth A. and Barry R. Weingast. 1987. The Institutional Foundations of Committee Power, American Political Science Review 81: 85-104.

[44] Stein, Robert M. 1981. The Allocation of Federal Aid Monies: The Synthesis of the Demand-side and Supply-side explanations, The American Political Science Review 75: 334-343.

[45] Strom, Gerald S. 1975. Congressional Policy-making: a test of a theory, Journal of Politics 37:711-735.

[46] Strömberg, D. 2004. Radio Impact on Public Spending, Quarterly Journal of Economics, 119:189-221. 
[47] Wallis, John J. 1987. Employment, Politics and Economic Recovery in the Great Depression, Review of Economics and Statistics 69: 516-20.

[48] Wright, Gavin. 1974. The Political Economy of New Deal Spending: an econometric analysis, Review of Economics and Statistics, 56: 30-38. 
Table 1: Average real percapita federal outlays by state during $\mathbf{1 9 8 2 - 2 0 0 0}$ 2000 real US Dollars percapita

State

Alabama

Arkansas

Arizona

California

Colorado

Connecticut

Delaware

Florida

Georgia

lowa

Idaho

Illinois

Indiana

Kansas

Kentucky

Luoisiana

Massachusets

Maryland

Maine

Michigan

Minnesota

Missouri

Mississippi

Montana

North Carolina

North Dakota

Nebraska

New Hampshire

New Jersey

New Mexico

Nevada

New York

Ohio

Oklahoma

Oregon

Pennsylvania

Rhode Island

South Carolina

South Dakota

Tennessee

Texas

Utah

Virginia

Vermont

Whashington

Wisconsin

West Virginia

Wyoming
Average federal outlays percapita

$\$ 5,339.52$

$\$ 4,713.85$

$\$ 4,992.98$

$\$ 5,210.48$

$\$ 5,277.46$

$\$ 5,912.66$

$\$ 4,477.32$

$\$ 5,238.06$

$\$ 4,564.36$

$\$ 4,564.12$

$\$ 4,682.08$

$\$ 4,183.07$

$\$ 4,057.55$

$\$ 5,107.32$

$\$ 4,810.72$

$\$ 4,748.89$

$\$ 6,112.77$

$\$ 7,428.26$

$\$ 5,345.58$

$\$ 4,030.17$

$\$ 4,316.81$

$\$ 6,176.43$

$\$ 5,324.57$

$\$ 5,512.15$

$\$ 4,137.82$

$\$ 6,182.13$

$\$ 4,836.17$

$\$ 4,371.64$

$\$ 4,670.97$

$\$ 7,279.27$

$\$ 4,585.21$

$\$ 5,108.39$

$\$ 4,442.29$

$\$ 4,861.50$

$\$ 4,320.66$

$\$ 5,074.75$

$\$ 5,493.86$

$\$ 4,815.52$

$\$ 5,430.08$

$\$ 5,002.15$

$\$ 4,403.46$

$\$ 4,475.27$

$\$ 7,636.12$

$\$ 4,430.62$

$\$ 5,482.99$

$\$ 3,942.40$

$\$ 5,016.49$

$\$ 5,065.97$ 
Table 2: Swing and Ideological Bias

Dependent variable: real percapita federal outlays, 1982-2000

\begin{tabular}{|c|c|c|}
\hline & (1) & $(2)$ \\
\hline Dependent Variable & fedexp & fedexp \\
\hline Share of vote for the incumbent president & $\begin{array}{l}1821.43 \\
(2.75)^{\star \star \star}\end{array}$ & $\begin{array}{c}1076.899 \\
(2.34)^{\star \star}\end{array}$ \\
\hline Closeness & $\begin{array}{c}-615.15 \\
(1.46)\end{array}$ & \\
\hline Swing & & $\begin{array}{c}-139.3107 \\
(1.25)\end{array}$ \\
\hline Electoral votes percapita & $\begin{array}{c}386.04 \\
(1.72)^{*}\end{array}$ & $\begin{array}{c}345.1779 \\
(1.55)\end{array}$ \\
\hline Observations & 864 & 864 \\
\hline R-squared & 0.9353 & 0.9347 \\
\hline
\end{tabular}

Table 3: Party Affiliation

Dependent variable: real percapita federal outlays, 1982-2000

\begin{tabular}{|c|c|c|}
\hline & (1) & (2) \\
\hline Dependent Variable & fedexp & fedexp \\
\hline Alignment Governor-President & $\begin{array}{l}134.904 \\
(2.35)^{\star \star}\end{array}$ & $\begin{array}{l}137.917 \\
(2.52)^{* *}\end{array}$ \\
\hline Alignment Governor-House & $\begin{array}{c}100.720 \\
(1.54)\end{array}$ & $\begin{array}{l}100.078 \\
(1.56)\end{array}$ \\
\hline Alignment Governor-Senate & $\begin{array}{l}12.3287 \\
(0.28)\end{array}$ & $\begin{array}{c}36.8956 \\
(0.86)\end{array}$ \\
\hline $\begin{array}{l}\text { Alignment between the Governor and the majority of } \\
\text { state delegates in the House }\end{array}$ & & $\begin{array}{l}-5.3423 \\
(0.11)\end{array}$ \\
\hline $\begin{array}{l}\text { Alignment between the Governor and the two state } \\
\text { senators }\end{array}$ & & $\begin{array}{c}-99.7257 \\
(1.60)\end{array}$ \\
\hline $\begin{array}{l}\text { Alignment between the President and the two state } \\
\text { senators }\end{array}$ & & $\begin{array}{l}22.1627 \\
(0.39)\end{array}$ \\
\hline $\begin{array}{l}\text { Alignment between the President and the majority of } \\
\text { state delegates in the House }\end{array}$ & & $\begin{array}{l}235.273 \\
(3.02)^{\star * *}\end{array}$ \\
\hline $\begin{array}{l}\text { Alignement between the majority of state delegates in } \\
\text { the House and the House majority }\end{array}$ & & $\begin{array}{c}71.001 \\
(0.93)\end{array}$ \\
\hline $\begin{array}{l}\text { Alignement between the two senators of the state and } \\
\text { the Senate majority }\end{array}$ & & $\begin{array}{l}36.5556 \\
(0.76)\end{array}$ \\
\hline Observations & 864 & 864 \\
\hline R-squared & 0.9273 & 0.9326 \\
\hline
\end{tabular}

OLS regressions; Robust t statistics in parentheses ( ${ }^{*}$ significant at $10 \% ;{ }^{* *}$ significant at $5 \%$; ${ }^{* * *}$ significant at $1 \%$ )

In all regressions the following controls are included: income, unemployment, population, percentage of aged, percentage of children, state fixed effects, year fixed effects, constant term. The alignment variables are dummies equal to one when partizan alignment occurs and zero otherwise. Detailed definitions of all variables are reported in the online statistical appendix. 
Table 4: Robustness Check

Dependent variable: real percapita federal outlays by program, 1982-2000

\begin{tabular}{|c|c|c|c|}
\hline & $(1)$ & $(2)$ & $(2)$ \\
\hline Dependent Variable & fedexp & & fedexp \\
\hline Allignment Governor-President & $\begin{array}{l}130.328 \\
(2.59)^{* *}\end{array}$ & $\begin{array}{l}118.372 \\
(2.39)^{\star *}\end{array}$ & $\begin{array}{l}126.028 \\
(2.71)^{\star \star *}\end{array}$ \\
\hline Alignment Governor-House & $\begin{array}{l}79.655 \\
(1.21)\end{array}$ & $\begin{array}{c}82.446 \\
(1.25)\end{array}$ & $\begin{array}{l}103.506 \\
(1.62)\end{array}$ \\
\hline Alignment Governor-Senate & $\begin{array}{l}15.453 \\
(0.36)\end{array}$ & $\begin{array}{l}15.604 \\
(0.36)\end{array}$ & $\begin{array}{l}-6.824 \\
(0.16)\end{array}$ \\
\hline $\begin{array}{l}\text { Alignment between President and the majo } \\
\text { state delegates in the House }\end{array}$ & $\begin{array}{l}84.470 \\
(1.75)^{*}\end{array}$ & $\begin{array}{l}-83.894 \\
(1.74)^{*}\end{array}$ & $\begin{array}{l}95.214 \\
(1.97)^{*}\end{array}$ \\
\hline Share of vote for the incumbent president & $\begin{array}{l}931.566 \\
(2.28)^{\star *}\end{array}$ & $\begin{array}{l}927.714 \\
(2.27)^{\star *}\end{array}$ & $\begin{array}{c}846.2 \\
(2.23)^{\star *}\end{array}$ \\
\hline Electoral votes percapita & $\begin{array}{c}338.140 \\
(1.42)\end{array}$ & $\begin{array}{c}339.285 \\
(1.41)\end{array}$ & $\begin{array}{c}-83.451 \\
(0.38)\end{array}$ \\
\hline Year of gubernatorial election & & $\begin{array}{l}-29.110 \\
(1.44)\end{array}$ & $\begin{array}{c}-33.372 \\
(1.70)^{*}\end{array}$ \\
\hline $\begin{array}{l}\text { Alignement Governor-President } \times \text { Year of } \\
\text { gubernatorial election }\end{array}$ & & $\begin{array}{l}61.575 \\
(2.23)^{\star *}\end{array}$ & $\begin{array}{l}63.519 \\
(2.31)^{\star *}\end{array}$ \\
\hline Appropriation & & & $\begin{array}{c}18.831 \\
(0.53)\end{array}$ \\
\hline Ways \& Means & & & $\begin{array}{l}76.618 \\
(2.28)^{\star *}\end{array}$ \\
\hline Budget & & & $\begin{array}{c}-18.715 \\
(0.85)\end{array}$ \\
\hline Rules & & & $\begin{array}{c}36.231 \\
(0.63)\end{array}$ \\
\hline Senators percapita & & & $\begin{array}{c}1,235.774 \\
(2.67)^{\star *}\end{array}$ \\
\hline Democratic President & & & $\begin{array}{c}1,012.155 \\
(10.56)^{\star * *}\end{array}$ \\
\hline Turnout & & & $\begin{array}{l}6.736 \\
(0.69)\end{array}$ \\
\hline Observations & 864 & 864 & 864 \\
\hline R-squared & 0.9367 & 0.9369 & 0.9413 \\
\hline
\end{tabular}

OLS regressions; Robust t statistics in parentheses ( ${ }^{*}$ significant at $10 \%$; ${ }^{* *}$ significant at $5 \%,{ }^{* * *}$ significant at $1 \%$ )

In all regressions the following controls are included: income, unemployment, population, percentage of aged, percentage of children, state fixed effects, year fixed effects, constant term. The alignment variables are dummies equal to one when partizan alignment occurs and zero otherwise. Detailed definitions of all variables are reported in the online statistical appendix. 


\section{Statistical Appendix}

\section{Summary Statistics (Table A1)}

Table A1 reports summary statistics of the variables we used in the paper.

\section{Multicollinearity (Tables A2-A4)}

Most of the explanatory variables used in the regressions could be correlated and therefore generate large standard errors. It is therefore important to verify whether the low significance of some variables, and especially of the closeness and swing variables, is due to multicollinearity. For this purpose we use the variance inflation factor (Chatterjee, Hadi and Price 2000) which, for a variable $x_{j}$ is given by:

$$
\operatorname{VIF}\left(x_{j}\right)=\frac{1}{1-R_{j}^{2}}
$$

where $R_{j}^{2}$ is the square of the multiple correlation coefficient that results when $x_{j}$ is regressed against all the other explanatory variables.

The variance of any $b_{j}$ coefficient in a multiple regression is:

$$
\operatorname{Var}\left[b_{j}\right]=\frac{\sigma^{2}}{\left(1-R_{j}^{2}\right) S_{x_{j} x_{j}}}
$$

where $\sigma^{2}$ is the square of the random disturbance and $S_{x_{j} x_{j}}$ is the variance of the $x_{j}$ variable. The bigger $R_{j}^{2}$ and therefore $\operatorname{VIF}\left(x_{j}\right)=\left(\frac{1}{\left(1-R_{j}^{2}\right)}\right)$, the greater is $\operatorname{Var}\left[b_{j}\right]$, for a given level of $\frac{\sigma^{2}}{S_{x_{j} x_{j}}}$. An informal rule of thumb applied by most analysts (Chatterjee, Hadi and Price, 2000) is that a variance inflation factor in excess of 20 may be evidence of multicollinearity.

In column 1 of table A2 we report the VIF relative to the regressions of table 2. In column 1 (which refers to column1 of Table 2) the variance inflation factor turns out to be 8.78 for the share of the presidential vote and and 7.12 for the closeness of the last presidential election. This means that the collinearity of these two variables with the other predictors is acceptable and does not significantly inflate the estimation of their standard errors. In the second column of table A2 (which refers to column 2 in Table 2) we obtain a VIF of 2.97 for the presidential share and of 2.13 for the swing variable. Hence, again, we can exclude that the low significance of the swing variable is due to multicollinearity. The only variable for which we detect a potential multicollinearity problem is the number of presidential electoral votes per capita with a $V I F=41.02$ which means that the standard error of this coefficient is highly inflated. Therefore, we should use caution in stating that the coefficient of this variable is not significant as it appears in the regression of column 2. In column 1 the number of electoral votes per capita is significant at the $10 \%$ level, again indicating that one should not underestimate the relevance of such variable. 
In Table A3 we report the results referred to Table 3 in the paper. In this case all variables display a VIF which is well below the threshold we established and therefore we can conclude that multicollinerarity is not a problem in these specifications.

Table A4 (which refers to Table 4 in the paper) is potentially the most problematic, since we include a number of indicators of alignment that are probably correlated. However, it appears from the VIFs that multicollinearity should not play a big role in inflating the standard errors of such variables. Once again, instead, we find that multicollineraity is a problem for the overrepresentation variables, namely the number of senators per capita and the number of electoral votes per capita. In the case of senators per capita this is not sufficient to render the estimation insignificant (the coefficient is in fact significat at the $5 \%$ level). In the case of electoral votes per capita we get an insignificant coefficient but this results should be clearly interpreted with some caution. Nevertheless, overrepresentation represents only a control factor for our regressions and the important point is that our variables of interest do not appear to suffer from a multicollinearity problem.

\section{More on the swing-voter hypothesis (Table A5)}

In the paper we reach the conclusion that swing states do not receive more federal funds, while states where the president obtains a larger share of votes tend to be rewarded. Our conclusion does not depend on the specific measure we use. In the paper we define a swing state in the following way:

- Define swing_last as a dummy equal to 1 if the state swung at the last presidential election. Let $i=1,2,3,4$ indicate the four previous presidential elections at each given time. Also, $t$ indicates the years and $k=1, \ldots 48$ indicates a state; then

$$
\text { swing }_{k t}=\sum_{i=1}^{4} \text { swing_last }_{k t} / 4 .
$$

In other words, swing 1 (indicated in the table as Long term swing 4 years average) is the average of swing_last over the previous four elections.

In this Appendix we report regressions where two alternative measures have been used. In column 1 of Table A5 we report regressions where swing_last has been used instead of swing. In column 2 of table A5 we use instead a variable defined as follows:

- Let $i=1,2, \ldots N$ indicate at each given time all previous presidential elections since 1964. Also, $t$ indicates the years and $k=1, \ldots 48$ indicates a state; then

$$
\operatorname{swing}_{k t}=\sum_{i=1}^{N} \text { swing_last }_{k t} / N .
$$


In other words, swing2 (indicated in the table as Long term swing since 1964) is in this case the average of swing_last over all elections between 1964 and $t$.

The results in table A5 show that such variations make very little difference. Our results are robust to the use of such alternative variables and continue to support the idea that swing states do not have any statistically significant advantage in terms of the receipt of federal funds.

In the column 3 of Table A5 we report an additional specification with respect to the swing-voter hypothesis. While we show that swing states do not receive more funds, it is still possible that the direction of the swing matters. In other terms, a greater allocation of funds could be expected for states that swing in the direction of the president as opposed to states that move away from him. Thus, in column 3 we introduce a dummy variable equal to 1 for states that swung in the direction of the president in the last election and an interaction term between this dummy and the swing variable. Both the dummy and the interaction turn out to be statistically insignificant. We conclude from this analysis that swing states do not receive more federal funds. 
Table A1: Summary Statistics

\begin{tabular}{|c|c|c|c|c|c|}
\hline Variable & Obs & Mean & Std. Dev & Min & Max \\
\hline Federal Expenditure per Capita* & 912 & 5066.518 & 983.5352 & 3005.729 & 8824.92 \\
\hline Alignment Governor-President & 960 & 0.40625 & 0.4913883 & 0 & 1 \\
\hline Alignment Governor-House & 960 & 0.5979167 & 0.4905742 & 0 & 1 \\
\hline Alignment Governor-Senate & 960 & 0.5208333 & 0.4998262 & 0 & 1 \\
\hline $\begin{array}{l}\text { Alignment between Governor and the } \\
\text { majority of state delegates to House }\end{array}$ & 960 & 0.421875 & 0.4941162 & 0 & 1 \\
\hline $\begin{array}{l}\text { Alignment between Governor and the } \\
\text { two senators**}\end{array}$ & 960 & 0.284375 & 0.4513514 & 0 & 1 \\
\hline $\begin{array}{l}\text { Alignment between President and the } \\
\text { two senators }{ }^{* *}\end{array}$ & 960 & 0.2645833 & 0.441341 & 0 & 1 \\
\hline $\begin{array}{l}\text { Alignment between President and the } \\
\text { majority of state delegates to House }\end{array}$ & 960 & 0.5333333 & 0.4991477 & 0 & 1 \\
\hline $\begin{array}{l}\text { Alignment between the majority of state } \\
\text { delegates to House and House majority }\end{array}$ & 960 & 0.5916667 & 0.4917816 & 0 & 1 \\
\hline $\begin{array}{l}\text { Alignment between the two senators } \\
\text { and the Senate majority }\end{array}$ & 960 & 0.3291667 & 0.4701555 & 0 & 1 \\
\hline Appropriation & 960 & 1.734375 & 1.430804 & 0 & 8 \\
\hline Ways \& Means & 960 & 0.5104167 & 0.7362899 & 0 & 4 \\
\hline Budget & 960 & 0.8104167 & 1.107137 & 0 & 6 \\
\hline Rules & 960 & 0.3177083 & 0.6161698 & 0 & 3 \\
\hline Closeness in Past Presid. Election & 960 & 0.1377484 & 0.1058159 & 0.0015169 & 0.5220283 \\
\hline Share of Votes for President & 960 & 0.5121536 & 0.0898193 & 0.2465447 & 0.7450179 \\
\hline State Elect. Votes per Capita & 960 & 2.714539 & 1.024855 & 1.527064 & 6.616543 \\
\hline Senators per Capita & 960 & 0.9661192 & 0.9851338 & 0.0588056 & 4.411028 \\
\hline Swing & 912 & 0.3723246 & 0.2042428 & 0 & 1 \\
\hline Democratic President & 960 & 0.4 & 0.4901533 & 0 & 1 \\
\hline Gubernatorial election year & 960 & 0.2625 & 0.4402222 & 0 & 1 \\
\hline Turnout & 960 & 61.02875 & 6.571284 & 46.1 & 75.6 \\
\hline Income per Capita* & 960 & 22954.47 & 4292.623 & 13796.28 & 41446.37 \\
\hline Unemployment & 960 & 6.074167 & 2.200156 & 2.2 & 18 \\
\hline Total Population & 960 & 5217.995 & 5497.381 & 453.409 & 34010.38 \\
\hline Share of population aged above 65 & 960 & 0.1239534 & 0.0199277 & 0.0468377 & 0.3663689 \\
\hline Share of Population aged 5-17 & 960 & 0.1910132 & 0.0226012 & 0.0233483 & 0.6194438 \\
\hline
\end{tabular}

Notes. *Federal Expenditure and Income are expressed in real value (year 2000).

**These variables take value equal to 1 when both senators are of the same political colour of, respectively, $t$ the Governor and the Presiden 
Table A2: VIF relative to the coefficients of the regressions in table 2

\begin{tabular}{lrr}
\hline Variable & $(1)$ & $(2)$ \\
\hline electoral votes per capita & 41.91 & 41.02 \\
share of votes for the president & 8.76 & 2.97 \\
closeness & 7.27 & \\
swing & & 2.13 \\
\hline
\end{tabular}

Table A3: VIF relative to the coefficients of the regressions in table 3

\begin{tabular}{lcr}
\hline Variable & $(1)$ & $(2)$ \\
\hline Alignment Governor-President & 3.59 & 3.69 \\
Alignment Governor-House & 4.03 & 4.62 \\
Alignment Governor-Senate & 1.67 & 1.75 \\
$\begin{array}{l}\text { Alignment between the Governor and the } \\
\text { majority of state delegates to the House }\end{array}$ & 2.03 \\
$\begin{array}{l}\text { Alignment between the Governor and } \\
\text { two state senators }\end{array}$ & 1.96 \\
$\begin{array}{l}\text { Alignment between the President and the } \\
\text { majority of state delegates in the House }\end{array}$ & 14.13 \\
$\begin{array}{l}\text { Alignment between the President and the } \\
\text { two state senators }\end{array}$ & & 1.63 \\
$\begin{array}{l}\text { Alignment between the majority of state } \\
\text { delegates in the House and the House majority }\end{array}$ & 13.70 \\
$\begin{array}{l}\text { Alignment between the two senators of the } \\
\text { State and the Senate majority }\end{array}$ & & 1.60 \\
\hline
\end{tabular}

Table A4: VIF relative to the coefficients of the regressions in table 4.

\begin{tabular}{lrrr}
\hline Variable & $(1)$ & $(2)$ & $(3)$ \\
\hline Alignment Governor-President & 3.61 & 3.84 & 3.91 \\
Alignment Governor-House & 4.05 & 4.06 & 4.14 \\
Alignment Governor-Senate & 1.68 & 1.68 & 1.73 \\
Alignement between the President and a & 2.35 & 2.35 & 2.54 \\
majority of state delegates to the House & & & \\
Share of votes for the incumbent President & 3.27 & 3.27 & 3.38 \\
Electoral votes per capita & 43.98 & 43.99 & 112.13 \\
Year of gubernatorial election & & 2.61 & 2.62 \\
Alignement Governor-President x Year of & & & \\
gubernatorial election & & 2.39 & 2.40 \\
Appropriation & & & 9.46 \\
Ways \& Means & & & 3.90 \\
Budget & & & 3.74 \\
Rules & & & 3.79 \\
Senators per capita & & & 17.17 \\
Democratic President & & & 10.19 \\
Turnout & & & \\
\hline
\end{tabular}


Table A5: More on Swing Bias

Dependent variable: real percapita federal outlays, 1982-2000

\begin{tabular}{|c|c|c|c|}
\hline & (1) & (2) & (3) \\
\hline Dependent Variable & fedexp & fedexp & fedexp \\
\hline Share of vote for the incumbent president & $\begin{array}{l}1154.21 \\
(2.66)^{\star *}\end{array}$ & $\begin{array}{l}1078.26 \\
(2.29)^{* *}\end{array}$ & $\begin{array}{l}1169.77 \\
(2.65)^{* *}\end{array}$ \\
\hline Long term Swing (4 years) & & & $\begin{array}{r}-16.51 \\
(0.09)\end{array}$ \\
\hline Swing_last & $\begin{array}{c}26.7636 \\
(0.57)\end{array}$ & & \\
\hline Long term Swing (since 1964) & & $\begin{array}{c}-147.04 \\
(1.02)\end{array}$ & \\
\hline State where the President won & & & $\begin{array}{c}-113.55 \\
(0.91)\end{array}$ \\
\hline $\begin{array}{l}\text { State where the President Won } \times \text { Long term } \\
\text { Swing }\end{array}$ & & & $\begin{array}{c}-140.90 \\
(0.66)\end{array}$ \\
\hline Electoral votes percapita & $\begin{array}{l}370.24 \\
(1.70)^{*}\end{array}$ & $\begin{array}{c}360.82 \\
(1.62)\end{array}$ & $\begin{array}{c}302.01 \\
(1.41)\end{array}$ \\
\hline Observations & 864 & 864 & 864 \\
\hline R-squared & 0.9348 & 0.9351 & 0.9369 \\
\hline
\end{tabular}

OLS regressions; Robust t statistics in parentheses ( ${ }^{*}$ significant at $10 \%$; ${ }^{* *}$ significant at $5 \%$; ${ }^{* *}$ significant at $1 \%$ )

In all regressions the following controls are included: income, unemployment, population, percentage of aged, percentage of children,

state fixed effects, year fixed effects, constant term. 
Table A6: More on Alignments

Dependent variable: real percapita federal outlays, 1982-2000

\begin{tabular}{lccc} 
& $(2)$ & $(3)$ & $(4)$ \\
\hline Dependent Variable & fedexp & fedexp & fedexp \\
\hline
\end{tabular}

Alignment between Governor and the majority of state delegates in the House

$-39.4412$

Alignment between Governor and the two state senators

Alignment between President and the two state senators

Alignment between President and the majority of state delegates in the House

175.688

$(3.13)^{* * *}$

Alignment between the majority of state delegates in the House and the House majority

Alignment between the two senators of the state and

\begin{tabular}{|c|c|c|}
\hline Observations & 864 & 864 \\
\hline R-squared & 0.9271 & 0.9292 \\
\hline
\end{tabular}




\section{List of variables: Definitions and Sources}

\section{From the Statistical Abstract of the US and the Bureau of Statistics}

Federal expenditure: real federal expenditure by state (year 2000 constant USD per capita).

Income: real income (year 2000 constant USD per capita).

Population: state population divided by 1000 .

Turnout: total percentage of voting population in the last presidential election.

Percentage of Aged: share of the population over 65 years old by state.

Percentage of Children: share of the population between 5 and 17 years old by state. Unemployment: unemployment rate.

Democratic president: dummy variable equal to 1 when the President is democratic, and zero when the President is republican.

Governor election year: dummy variable equal to 1 during a governor election year and zero otherwise.

\section{Authors' elaboration on data from the Statistical Abstract of the United States}

Closeness: distance in the percentage of vote (by state) between the winner of the presidential race and the runner up.

Share of vote for the incumbent president: share of votes for the current President in the last presidential elections.

Last election swing: dummy equal to 1 if the state swung at the last presidential election.

Swing: moving average of "Last election swing" over the four previous presidential elections at each given time.

Long term swing: average of "Last election swing" from 1964 to the last election.

Alignment Governor-President: dummy variable equal to one when the party affiliation of the governor is the same as that of the President, and zero otherwise.

Alignment Governor-House: dummy variable equal to one when the party affiliation of the governor is the same as that of the majority of the House, and zero otherwise.

Alignment Governor-Senate: dummy variable equal to one when the party

affiliation of the governor is the same as that of the majority of the Senate, and zero otherwise.

Senators percapita: 2000/Population.

Electoral votes percapita: $(1000 \times$ Electoral votes $) /$ Population

Alignment between the governor and the two state senators: dummy variable equal to one when the governor is from the same party of both senators in the state, and zero otherwise.

Alignment between the Governor and the majority of state delegates in the House: dummy variable equal to one when the governor is from the same party as the majority of state delegates in the House, and zero otherwise.

Alignment between the President and the two state senators: dummy variable equal to 1 if both senators from a state are of the same party of the President. 
Alignment between the President and the majority of state delegates in the

House: dummy variable equal to 1 if a majority of state delegates in the House are of the same party of the President.

Alignment between the majority of state delegates in the House and the House majority: dummy variable equal to 1 if a majority of state delegates to the House are in the majority party in the House.

Alignment between the two senators of the state and the Senate majority: dummy variable equal to 1 if a majority of state delegates to the Senate are in the majority party in the Senate.

From the Official Congressional Directory and from Nelson and Bensen (1993).

Appropriation: number of members in the House appropriation committee by state. Budget: number of members in the House Budget committee by state.

Rules: number of members in the House Rules committee by state.

Ways \& Means: number of members in the Ways and Means committee by state. 